\title{
PENGARUH PENGGUNAAN MODEL PEMBELAJARAN TALKING STICK TERHADAP AKTIVITAS BELAJAR DAN HASIL BELAJAR PADA MATA PELAJARAN EKONOMI KELAS X DI SMA NEGERI BANDARKEDUNGMULYO JOMBANG TAHUN AJARAN 2012/2013
}

\author{
Yahya Reka Wirawan \\ Dosen Prodi. Pendidikan Ekonomi IKIP PGRI Madiun
}

\begin{abstract}
Abstrak: Selama ini proses pembelajaran kita lihat masih menganut model pembelajaran konvensional, yaitu proses pembelajaran yang berpusat pada guru dan selama itu pula kemampuan siswa untuk aktif dalam proses pembelajaran dan kemandirian dalam belajar tidak akan tampak. Pembelajaran konvensional menganggap guru adalah satu-satunya sumber belajar yang dianggap serba tahu. Hal ini di perkuat oleh hasil observasi yang telah dilkukan oleh peneliti sebelum melakukan penelitian, dan terbukti saat pelajaran dimulai banyak siswa yang ngobrol sendiri dan kelihatan sekali mereka merasa bosan dengan metode yang dilakukan oleh guru mata pelajaran ekonomi. Hal ini di duga akan mempengaruhi aktivitas belajar dan hasil belajar siswa di dalam kelas.Penelitian ini dilaksanakan di Perak Jombang, tepatnya di SMA Negeri Bandarkedungmulyo 1.Penelitian ini merupakan PTK (Penelitian Tindakan Kelas). Tahap penelitian berupa siklus yang meliputi: perencanaan, pelaksanaan, observasi, dan refleksi. Teknik - teknik pengumpulan data yang digunakan yaitu: observasi; pengukuran tes hasil belajar; dan dokumentasi. Berdasarkan hasil penelitian yang telah dilaksanakan disimpulkan bahwa penggunaan model pembelajaran talking stick terhadap aktivitas belajar dan hasil belajar siswa berpengaruh baik.Dari hasil penelitian menunjukkan bahwa penggunaan model pembelajaran talking stick terhadap aktivitas belajar dan hasil belajar siswa berpengaruh baik, khususnya pada mata pelajaran ekonomi. Hal ini terbukti pada siklus I aktivitas belajar siswa dengan nilai rata - rata kelas dari pre test sebesar 31 meningkat menjadi 35 atau sekitar $12,9 \%$ Sedangkan pada siklus II aktivitas belajar siswa mengalami peningkatan yakni nilai rata-rata kelas dari pre test sebesar 35 meningkat menjadi 45 atau sekitar $28,57 \%$. Pada siklus I hasil belajar siswa dengan nilai rata - rata kelas dari pre test sebesar 80,12 meningkat menjadi 84,71 atau sekitar 5,72\%, sedangkan pada siklus II hasil belajar siswa mengalami peningkatan, yakni nilai rata - rata pre test sebesar 84,71 meningkat menjadi 92,35 atau sekitar 9,02\%
\end{abstract}

Kata Kunci : Model Pembelajaran Talking Stick, Aktivitas Belajar, Hasil Belajar

\section{PENDAHULUAN}

Pendidikan adalah suatu hal yang mutlak yang harus dipenuhi dalam upaya meningkatkan taraf hidup bangsa Indonesia agar tidak sampai tertinggal dengan bangsa lain. Oleh karena itu, untuk menghadapi tantangan sesuai tuntutan perkembangan zaman, perlu diadakan perbaikan kualitas pendidikan nasional, yaitu memperbaiki kualitas kurikulum, meningkatkan kompetensi guru, mengingkatkan kualitas pembelajaran, mengefektifkan metode pembelajaran, meningkatkan kualitas sarana dan prasarana belajar dan bahan ajar yang memadai. Salah satu upaya pemerintah dalam memperbaiki kualitas kurikulum adalah dengan melakukan penyempurnaan kurikulum. 
Keberhasilan pendidikan di suatu sekolah dipengaruhi oleh banyak faktor, antara lain guru, siswa, kurikulum, strategi pembelajaran, lingkungan belajar dan lainnya.Guru dan siswa merupakan dua faktor terpenting dalam proses pembelajaran. Pentingnya faktor guru dan siswa dapat dituntut melalui pemahaman hakekat pembelajaran, yakni sebagai proses membangun pemahaman terhadap informasi dan pengalaman. Proses membangun pemahaman tersebut dapat dilakukan sendiri oleh siswa atau bersama orang lain. Proses itu disaring dengan persepsi, pikiran, dan perasaan siswa (Indra Jati Sidi, 2004).

Pembelajaran Ekonomi selama ini cenderung lebih banyak mengembangkan kemampuan menghafal materi pelajaran. Siswa belum dibiasakan untuk memahami informasi dan menghubungkan dengan kehidupan sehari-hari. Pembelajaran Ekonomi masih berpusat pada guru dan siswa belum dijadikan subjek belajar. Pembelajaran cenderung lebih banyak menempatkan siswa pada aktivitas mencatat, mendengar, atau menjawab pertanyaan guru. Proses pemahaman harus diimbangi dengan strategi pembelajaran yang diterapkan. Strategi pembelajaran yang diterapkan oleh guru harus mampu mengarahkan siswa supaya dalam belajar siswa tidak hanya sekedar mengingat, tetapi harus benar-benar mengerti dan dapat menerapkan ilmu pengetahuan mereka sehingga mereka bisa bekerja untuk memecahkan masalah, menemukan sesuatu bagi dirinya sendiri, dan selalu bergulat dengan ide-ide (M. Nur, dkk, 2000).

Keterlibatan guru hanya sebagai fasilitator dan moderator dalam proses pembelajaran tersebut. Menurut Winkel (2005) menyatakan, untuk mencapai hasil pendidikan yang lebih baik, bentuk program pendidikan sekolah haruslah berpusat pada aktivitas belajar siswa, sehingga proses belajar yang terjadi pada siswa lebih bermakna dan hasil belajar siswa mencapai tingkat yang memuaskan. Seorang guru didalam melaksanakan kewajibannya tidak jarang mengalami kendala dalam melakukan proses belajar mengajar. Masalah yang timbul bisa bersumber dari dalam diri dan bisa juga timbul dari pihak luar diri guru itu sendiri. Salah satu masalah yang timbul dari dalam diri guru yaitu guru lebih banyak menempatkan siswa sebagai objek dan bukan sebagai subjek pendidikan. Kondisi pembelajaran seperti itu tentunya akan berdampak pada hasil belajar siswa.

Talking stick adalah sebuah metode pembelajaran yang tergolong dalam metode PAIKEM, yaitu metode Pembelajaran Aktif, Inovatif, Kreatif, Efektif dan Menyenangkan. jadi Talking Stick merupakan bagian dari PAIKEM. Model pembelajaran Talking Stick akan mendorong siswa untuk lebih menguasai materi. Konsep model pembelajaran Talking Stick akan mendorong guru dan siswa melaksanakan praktek pembelajaran secara aktifdan kreatif sehingga diharapkan tercapainya peningkatan aktivitas belajar dan hasil belajar secara optimal. Dalam model ini akan diadakan permainan dimana guru akan memberikan tongkat kepada seorang siswa, siswa yangmendapatkan tongkat harus menjawab pertanyaan dari guru. Dengan menggunakan model pembelajaran ini diharapkan guru dan siswa dapat melaksanakan proses pembelajaran dengan tepat, siswa dapat memahami mata pelajaran yang ada di kelas dan meningkatkan aktivitas belajar dan hasil belajar siswa.

Aktivitas belajar adalah seluruh aktivitas siswa dalam proses belajar, mulai dari kegiatan fisik sampai kegiatan psikis. Kegiatan fisik berupa ketrampilanketrampilan dasar sedangkan kegiatan psikis berupa ketrampilan terintegrasi. Ketrampilan dasar yaitu mengobservasi, mengklasifikasi, memprediksi, mengukur, menyimpulkan dan mengkomunikasikan. Sedangkan ketrampilan terintegrasi terdiri dari mengidentifikasi variabel, membuat tabulasi data, menyajikan data dalam bentuk grafik, menggambarkan hubungan antar variabel, mengumpulkan dan 
mengolah data, menganalisis penelitian, menyusun hipotesis, mendefinisikan variabel secara operasional, merancang penelitian dan melaksanakan eksperimen.

Hasil belajar adalah nilai yang menggambarkan tingkat pemahaman siswa setelah mengikuti pelajaran. Hasil belajar, untuk sebagian adalah berkat tindak guru, suatu pencapaian tujuan pengajaran. Pada bagian lain, merupakan peningkatan kemampuan mental siswa. Hasil belajar tersebut dibedakan menjadi dampak pengajaran, dan dampak pengiring. Dampak pengajaran adalah hasil yang dapat diukur, seperti tertuang dalam angka rapor, angka dalam ijazah, atau kemampuan meloncat setelah latihan. Dampak pengiring adalah terapan pengetahuan dan kemampuan di bidang lain, suatu transfer belajar (Dimyati dan Mudjiono, 2006). Menurut Anni (2004:4) hasil belajar merupakan perilaku yang diperoleh pembelajar setelah mengalami aktivitas belajar. Perolehan aspek-aspek perubahan perilaku tersebut tergantung pada yang dipelajari oleh pembelajar. Jika pembelajar mempelajari pengetahuan tentang konsep, maka perubahan perilaku yangdiperoleh adalah berupa penguasaan konsep.

Pentingnya penelitian ini dilakukan untuk mengkaji lebih dalam tentang: a) pengaruh penggunaan model pembelajaran talking stick terhadap aktivitas belajar siswa, b) pengaruh penggunaan model pembelajaran talking stick terhadap hasil belajar siswa, serta c) pengaruh penggunaan model pembelajaran talking stick terhadap aktivitas belajar dan hasil belajar siswa.

\section{METODE PENELITIAN}

Pendekatan yang digunakan dalam penelitian ini adalah pendekatan kuantitatif sedangkan variabel dalam penelitian ini adalah model pembelajaran talking stick sebagai variabel independen sedangkan aktivitas belajar siswa dan hasil belajar siswa sebagai variabel dependen. Populasi dalam penelitian ini siswa kelas X, XI IPA dan IPS,
XII IPA dan XII IPS di SMA Negeri Bandar Kedung Mulyo Jombang yang berjumlah 540 siswa. Sampel penelitian sebesar 34 siswa.Teknik sampling yang digunakan teknik propotional random sampling.

Metode pengumpulan data yang digunakan dalam penelitian ini adalah metode observasi, interview, studi documenter, dan pengukuran pre test hasil belajar. Teknik analisis data yang digunakan dalam penelitian ini adalah Analisis data digunakan dengan menggunakan teknik analisis kualitatif. Data kualitatif dianalisis dengan teknik deskriptif dan interpretative berdasarkan teori pembelajaran yang digunakan. Data dikumpulkan selama tindakan kelas. Hal ini dilakukan agar tidak terjadi penumpukan data dan penulis segera memberikan refleksi terhadap data sehingga proses pemberian makna dan kesimpulan diambil bisa lebih cepat. Data yang diperoleh dari tindakan yang dilakukan dianalisis untuk memastikan bahwa dengan mengaplikasikan pembelajaran metode Talking Stick dapat meningkatkan aktivitas siswa.Data yang bersifat kualitatif yang terdiri dari hasil observasi dan dokumentasi dianalisis secara kualitatif.

\section{HASIL DAN PEMBAHASAN}

Hasil pre test menunjukkan bahwa pada pelaksanaan pre test, siswa terlihat kurang antusias terhadap pelajaran, mereka terlihat kurang dapat mengikuti kegiatan belajar mengajar dengan baik. Hal itu diketahui dari kurangnya rasa ingin tahu mereka terhadap materi yang akan diberikan. Kebanyakan dari mereka kelihatannya jenuh terhadap pelajaran. Karena aktivitas siswa terhadap pelajaran kurang, maka hasil belajar mereka juga kurang maksimal. Dari hasil evaluasi pada saat pre test, didapatkan rata-rata kelas sebesar $\mathbf{8 0 , 1 2}$ 
Tabel Hasil Pre Test

\begin{tabular}{|c|c|c|c|c|}
\hline NO & NIS & NAMA & $\mathbf{L} / \mathbf{P}$ & $\begin{array}{c}\text { NILAI } \\
\text { PRE } \\
\text { TEST }\end{array}$ \\
\hline 1 & 2998 & $\begin{array}{l}\text { AHMAD SOFA NASRUL } \\
\text { FIRDAUS }\end{array}$ & $\mathrm{L}$ & 85 \\
\hline 2 & 3009 & APRILIA NURAINI & $P$ & 79 \\
\hline 3 & 3014 & ARIEF AULIA PRATAMA & $\mathrm{L}$ & 76 \\
\hline 4 & 3020 & ARIK AGUSTINA & $\mathrm{P}$ & 72 \\
\hline 5 & 3022 & AYU NINGTYAS & $\mathrm{P}$ & 77 \\
\hline 6 & 3028 & BAGUS ANGGARA PUTRA & $\mathrm{L}$ & 77 \\
\hline 7 & 3032 & CANDRA ADI PRASETYO & $\mathrm{L}$ & 75 \\
\hline 8 & 3033 & DARIYANTI & $\mathrm{P}$ & 72 \\
\hline 9 & 3041 & DENIS PRIYAMBODO & $\mathrm{L}$ & 83 \\
\hline 10 & 3058 & DHANI YOGA PRATAMA & $\mathrm{L}$ & 78 \\
\hline 11 & 3062 & EVA SEPTIAWATI & $\mathrm{P}$ & 79 \\
\hline 12 & 3071 & FERDIAN BUDI AR-ROUF & $\mathrm{L}$ & 77 \\
\hline 13 & 3077 & FIRDA MAHARANI & $\mathrm{P}$ & 85 \\
\hline 14 & 3080 & $\begin{array}{l}\text { FITRI CHUSNUL } \\
\text { KHOTIMAH }\end{array}$ & $\mathrm{P}$ & 78 \\
\hline 15 & 3081 & GALIH PRAKOSO & $\mathrm{L}$ & 85 \\
\hline 16 & 3087 & $\begin{array}{l}\text { IGUSTI MEGA SEKAR } \\
\text { ARUM }\end{array}$ & $P$ & 78 \\
\hline 17 & 3091 & $\begin{array}{l}\text { IMAM MACHMUDI } \\
\text { DZIKRULLOH }\end{array}$ & $\mathrm{L}$ & 78 \\
\hline 18 & 3092 & $\begin{array}{l}\text { INDAH WAHYUNINGTYAS } \\
\text { RESMI P }\end{array}$ & $\mathrm{P}$ & 77 \\
\hline 19 & 3105 & $\begin{array}{l}\text { KUMORO SETYO } \\
\text { PRIANGGO }\end{array}$ & $\mathrm{L}$ & 85 \\
\hline 20 & 3115 & $\begin{array}{l}\text { MASAYU HUSNUL } \\
\text { CHOTIMAH }\end{array}$ & $\mathrm{P}$ & 71 \\
\hline 21 & 3120 & $\begin{array}{l}\text { MILLA KHOIRUN } \\
\text { NADLIROH }\end{array}$ & $\mathrm{P}$ & 87 \\
\hline 22 & 3121 & MOCHAMAD IRFAN & $\mathrm{L}$ & 88 \\
\hline 23 & 3144 & POPPY GIAN ANJARSARI & $\mathrm{P}$ & 76 \\
\hline 24 & 3147 & PUPUT NOVITA SARI & $\mathrm{P}$ & 76 \\
\hline 25 & 3151 & RACHMAD PANJI SATYA & $\mathrm{L}$ & 76 \\
\hline 26 & 3152 & RADITA IRA PUSPITASARI & $\mathrm{P}$ & 93 \\
\hline 27 & 3154 & $\begin{array}{l}\text { RAGIL TEGAR } \\
\text { BAGASKARA }\end{array}$ & $\mathrm{L}$ & 91 \\
\hline 28 & 3156 & $\begin{array}{l}\text { RATNA NOVIANTI } \\
\text { SHOLIKHA }\end{array}$ & $\mathrm{P}$ & 87 \\
\hline 29 & 3160 & RETNO SARI ANGGRAINI & $\mathrm{P}$ & 80 \\
\hline 30 & 3169 & SEPTY YUANITA & $\mathrm{P}$ & 80 \\
\hline 31 & 3184 & WAHYU DWI CAHYO & $\mathrm{L}$ & 86 \\
\hline 32 & 3192 & $\begin{array}{l}\text { YULIANTRI PEA DEO } \\
\text { RAHMA }\end{array}$ & $P$ & 76 \\
\hline 33 & 3193 & YUNA RIZKY OCTANIA & $\mathrm{P}$ & 73 \\
\hline 34 & 3198 & ZONA REZADDIEN AQOBA & $\mathrm{L}$ & 88 \\
\hline \multicolumn{4}{|c|}{ RATA - RATA } & 80,12 \\
\hline
\end{tabular}

Pada saat siklus pertama selama kegiatan pembelajaran, peneliti bertindak sebagai guru dan teman sejawat sebagai observer. Hasil pengamatan pada siklus I, kegiatan siswa cukup baik dengan cukup antusias dan merespon positif mengikuti kegiatan belajar mengajar. Mulai adanya peningkatan aktivitas belajar dibandingkan pada saat pre test. Hal ini terlihat dari aktivitas siswa pada saat mengerjakan pre test takut salah, pada siklus I ini mereka sudah mulai berani menjawab meskipun bobot jawaban rata-ratanya adalah 80,12 mereka masih belum mencapai seperti yang diharapkan. Pada saat kegiatan belajar mengajar berlangsung, para siswa tampak gembira dan senang, hal ini dapat dilihat dari wajah mereka yang tampak memancarkan semangat dan antusias untuk belajar meskipun masih ada beberapa siswa yang belum terbiasa dengan model pembelajaran yang diterapkan oleh peneliti.

Hasil pengamatan pada tahap kegiatan awal, terdapat peningkatan aktivitas, hal ini dikarenakan siswa merasa mendapatkan penyegaran dalam kegiatan belajar mengajar, sehingga mereka berusaha memusatkan perhatian selama pembelajaran berlangsung. Akan tetapi, memasuki kegiatan penjelasan materi secara global, aktivitas siswa dalam menjawab pertanyaan masih kurang. Hal ini dikarenakan siswa masih belum terbiasa untuk menjawab pertanyaan secara langsung yang dapat membuat mereka merasa takut untuk menjawab.

Memasuki kegiatan inti, langkah yang dilakukan peneliti adalah menyampaikan kompetensi dasar dan pengetahuan tentang pembelajaran inovatif yang menggunakan metode talking Stick kepada peserta didik. Setelah peneliti memberikan gambaran tentang pembelajaran inovatif metode talking Stick kemudian peneliti memberikan kesempatan kepada peserta didik untuk bertanya apabila belum mengerti tentang pembelajaran inovatif metode talking stick agar nantinya ketika pelaksanaanya semua peserta didik mampu mengikuti dengan baik. Dan selanjutnya guru melaksanakan proses belajar mengajar dengan menggunakan 
metode talking stick untuk meningkatkan aktivitas belajar dan hasil belajar siswa tentang materi permintaan dan faktor - faktor yang mempengaruhinya. Supaya mereka mudah termotivasi keterangan guru, guru sebagai peneliti langsung menerapkan metode talking stick, guru pertama kali menjelaskan materi yang akan diajarkan, selanjutnya siswa diberi kesempatan dalam waktu 10 menit untuk mempelajari materi yang telah disampaikan oleh guru, pada tahap selanjutnya semua siswa diminta untuk menutup bukunya dan memberikan tongkat pada salah satu siswa untuk di lemparkan pada teman sebelahnya sambil menyanyikan lagu di sini senang di sana senang, sampai lagu habis dan tongkat dipegang oleh salah satu siswa dan siswa tersebutlah yang mendapat pertanyaan dari guru. Siswa pertama kali melaksanakan metode ini gugup karena siswa masih merasa takut dengan pertanyaan yang secara langsung di lemparkan kepada siswa, pada saat tongkat dilempar siswa semangat dengan bernyanyi lagu di sini senang di sana senang dan pada saat tongkat berhenti pada salah satu siswa kebanyakan siswa merasa takut jawabannya yang salah atau kurang tepat, dan guru selanjutnya memberi pertanyaan kepada masing-masing siswa sampai semua siswa mendapat giliran pertanyaan dan begitu seterusnya.

Berdasarkan hasil pengamatan, diketahui bahwa aktivitas belajar dan hasil belajar siswa masih belum seperti yang diharapkan atau bisa dikatakan masih rendah. Ini dapat dilihat dari lembar observasi siswa yang menunjukkan bahwa aktivitas memperhatikan siswa belum mencapai apa yang diharapkan. Kegiatan ini masih di dominasi oleh para siswa yang aktif, sedangkan mereka yang pasif cenderung memperhatikan saja. Hal ini dikarenakan adanya perbedaan individual pada masing-masing siswa. Mereka yang aktif adalah mayoritas yang memiliki prestasi di kelas, dan mereka yang pasif adalah yang berprestasi kurang atau sedang dan mereka cenderung kurang percaya diri pada kemampuannya.

Selanjutnya, untuk mengetahui tingkat aktivitas belajar siswa terhadap materi pelajaran ekonomi, guru melakukan feed back terhadap hasil yang dicapai siswa dan memberikan tugas untuk mencari sendiri dalam buku bacaanya tentang permintaan dan faktor-faktor yang mempengaruhinya dengan dibatasi waktu sekitar 15 menit, sehingga siswa bersemangat untuk menyelesaikan tugas yang cepat dan tepat.

Hasil pengamatan menunjukkan bahwa dengan tugas seperti ini siswa cukup termotivasi untuk mengerjakan tugas dengan sebaik-baiknya. Seluruh siswa cukup antusias dan tertarik untuk menyelesaikan tugas. Indikator peningkatan aktivitas belajar siswa tercermin dalam semangat, antusias dan rasa ingin tahu siswa dalam KBM.

Berdasarkan hasil observasi yang telah dilaksanakan terdapat sedikit peningkatan aktivitas belajar siswa yang semula nilai ratarata kelas dari pre test sebesar 31 meningkat menjadi 35 atau $12,9 \%$ dan peningkatan hasil belajar siswa yang semula nilai rata-rata kelas dari pre test sebesar 80,12 meningkat menjadi 84,71 atau sekitar 5,72\%.

Pada siklus II ini, hasil pengamatan menunjukkan bahwa siswa mengalami peningkatan aktivitas belajar yang cukup menggembirakan dalam mengikuti kegiatan belajar mengajar, siswa sudah lebih terbiasa menjawab pertanyaan yang diberikan oleh guru.

Pada tahap kegiatan awal, kegiatan siswa cukup bagus. Hal ini dapat dilihat dari:

1) siswa sangat antusias mengikuti kegiatan belajar mengajar.

2) pada saat penjelasan materi secara global siswa sudah siap menjawab pertanyaan dari guru dan juga berani mengajukan pertanyaan dan pendapat.

Memasuki kegiatan inti, ketika guru melaksanakan model pembelajaran talking stick mereka sangat menikmatinya dan tidak ada lagi rasa takut, gugup dan malu. Mereka tampak bersemangat dalam menjawab 
pertanyaan dan menyelesaikan tugas yang diberikan oleh guru. Mereka saling membantu memahami materi yang diberikan. Mereka saling melontarkan pertanyaan demi tercapainya hasil belajar yang memuasakan serta menampakkan rasa gembira dan senang selama mengikuti pembelajaran. Tidak tampak rasa letih dari wajah mereka, bahkan ketika peneliti memberi kesempatan untuk mengajukan pertanyaan, dengan serentak para siswa berebut bertanya kepada guru, sehingga tidak sia-sia peneliti menggunakan model pembelajaran talking stick untuk meningkatkan aktivitas belajar dan hasil belajar siswa. Karena siswa sudah berani menjawab pertanyaan dari guru. Peneliti menangkap komunikasi dan kerjasama yang sudah sangat baik bahkan dapat dikatakan begitu dinamis dan sempurna pada masingmasing siswa, karena masing-masing siswa merasa tidak ada beban rasa malu dan takut salah dalam menjawab dan mengajukan pendapat.

Indikator peningkatan aktivitas belajar siswa tercermin dalam bertambahnya semangat, antusias dan rasa ingin tahu siswa dalam KBM. Sedangkan indikator peningkatan aktivitas belajar siswa terlihat dari meningkatnya hasil belajar siswa.

Berdasarkan hasil observasi yang telah dilaksanakan terdapat peningkatan aktivitas belajar siswa yang semula nilai rata-rata kelas dari siklus I sebesar 35 meningkat pada siklus II menjadi 45 atau 28,57\%. Dan peningkatan hasil belajar siswa terlihat dari nilai rata-rata kelas yang semula nilai rata-rata kelas dari siklus I sebesar 84,71 meningkat menjadi pada siklus II 92,35 atau sekitar 9,02\%.

Pada siklus I, materi diberikan selama satu kali pertemuan, dengan perincian pada pertemuan pertama diberikan materi tentang permintaan dan faktor-faktor yang mempengaruhinya. Pada siklus I ini sebelum siswa diberikan tugas-tugas, guru melakukan pembahasan materi tentang rencana pembelajaran dan mendiskusikan tentang topik pelajaran yang dikaitkan dengan konteks kehidupan siswa sehari-hari. Hal ini diasumsikan dapat menarik perhatian siswa terhadap pelajaran yang diberikan guru sebab semakin jelas apa yang ingin dicapai guru bersama siswa semakin mudah dia dapat mencapainya dan semakin mudah pula dia dapat menyimpulkan apakah ia sudah mencapai tujuan atau belum, dan tentunya juga diharapkan dapat meningkatkan aktivitas belajar dan hasil belajar siswa.

Pada pertemuan pertama, siswa terlihat kurang dapat mengikuti KBM dengan baik. Hal ini dapat diketahui dari kurangnya rasa ingin tahu mereka terhadap materi yang akan diberikan serta minimnya pertanyaan atau jawaban yang telah dilontarkan guru kepada siswa saat metode talking stick berlangsung.

Mereka terlihat kebingungan dengan apa yang akan mereka pertanyakan atau apakah yang harus mereka jawab karena kebanyakan mereka belum siap menjawab pertanyaan dari guru. Akan tetapi antusias mereka terhadap tugas yang diberikan cukup baik.Hal ini ditunjukkan dari semangat dan kegembiraan mereka selama mengikuti pembelajaran.Tetapi lama kelamaan siswa tampak mulai menunjukkan rasa ingin tahu yang cukup besar.Hal ini dapat dilihat dari munculnya pertanyaan-pertanyaan dan beberapa jawaban dari siswa ketika guru membuka pertanyaan.Di awal pembelajaran siswa pun tampak bersemangat dalam mengerjakan tugas dan berusaha mengerjakannya dalam waktu yang ditentukan, meskipun hasilnya belum sesuai dengan yang diharapkan. Model pembelajaran talking stick sudah mulai tampak bisa diterima oleh siswa meskipun masih ada beberapa siswa yang pasif dan lamban menerimanya.

Berdasarkan observasi awal yang dilakukan peneliti, siswa kelas X - 2 cenderung pasif dalam proses pembelajaran mata pelajaran ekonomi. Aktivitas belajar dan hasil belajar para siswa sangat tergantung pada guru, hal ini dikarenakan siswa kurang di libatkan secara aktif dalam proses pembelajaran. Guru masih menggunakan model 
pembelajaran konvensional yakni metode ceramah, mencatat di papan tulis dan memberi tambahan nilai dengan memberikan pekerjaan rumah.

Dengan menggunakan model pembelajaran yang bersifat mengajak para siswa untuk berperan aktif dalam proses pembelajaran, dan tidak membuat mereka merasa bosan. seperti seperti dengan menggunakan model pembelajaran talking stick ini akan dapat merubah kebiasaan siswa yang cenderung pasif dan hanya terpusat pada guru akan menjadi suatu proses pembelajaran yang akan membuat siswa dapat memahami materi pelajaran dengan mudah dan lebih bertahan lama, serta mereka juga akan merasakan proses pembelajaran yang menyenangkan dan tidak membosankan. Akan tetapi, tidak semua materi dalam kurikulum bisa menggunakan metode ini, seperti materi perhitungan, karena untuk materi perhitungan siswa terlalu sulit untuk belajar sendiri, dan untuk tanya jawabnya siswa akan kesulitan. Materi-materi yang bias menggunakan metode ini adalah materi-materi yang bersifat hafalan yang mudah dicerna dan dipahami oleh siswa.

Pembelajaran mata pelajaran ekonomi yang dilaksanakan oleh peneliti dengan menggunakan pembelajaran inovatif talking stick. Dalam proses pembelajaran ini para siswa dituntut untuk berpartisipasi secara aktif sehingga dalam proses pembelajaran aktivitas siswa sangat tinggi, model pembelajaran ini mengajak para peserta didik untuk belajar sambil bermain sehingga mereka tidak merasa bosan ataupun tidak semangat ketika mengikuti proses pembelajaran.

Adapun langkah-langkah dalam pelaksanaan metode talking stick antara lain sebagaiberikut :

1. guru menyiapkan sebuah tongkat

2. guru menyampaikan materi pokok yang akan dipelajari, kemudian memberikan kesempatan kepada siswa untuk untuk membaca dan mempelajari materi pada pegangannya/paketnya.

3. setelah selesai membaca buku dan mempelajarinya mempersilahkan siswa untuk menutup bukunya

4. guru mengambil tongkat dan memberikan kepada siswa, setelah itu guru memberikan pertanyaan dan siswa yang memegang tongkat tersebut harus menjawabnya, demikian seterusnya sampai sebagian besar siswa mendapat bagian untuk menjawab setiap pertanyaan dari guru

5. guru memberikan kesimpulan

6. evaluasi

7. penutup

Pelaksanaan penelitian ini menerapkan menggunakan model pembelajaran talking stick melalui beberapa kegiatan pembelajaran diantaranyan yaitu :

A. Penjelasan Tentang Peraturan Dalam Proses Pembelajaran

Peneliti menjelaskan tentang aturan main dalam proses pembelajaran dengan menggunakan model pembelajaran talking stick bahwa para siswa nantinya akan diajak bermain sambil belajar yakni dengan memegang tongkat secara bergiliran sambil bernyanyi, peserta didik harus dapat menjawab pertanyaan yang diberikan oleh guru bagi yang memegang tongkat ketika nyanyian di hentikan sejenak, dan begitu seterusnya. Namun sebelum itu peneliti membagikan modul atau bahan ajar kepada siswa dengan tujuan sebagai pegangan ataupun pedoman dalam belajar. Pada tahap awal setelah peneliti membagikan bahan ajar kepada para siswa, maka peneliti akan menjelaskan secara singkat tentang inti materi yang akan dipelajari serta memberikan kesempatan kepada siswa untuk bertanya mengenai hal ataupun materi yang belum di mengerti dan sesekali peneliti juga memberikan pertanyaan kepada siswa mengenai apa yang telah disampaikan. Setelah itu peneliti memberikan kesempatan para siswa 
untuk belajar secara mandiri mengenai materi yang telah disampaikan sebelum proses pembelajaran dengan menggunakan model pembelajaran talking stick dilaksanakan, kemudian peneliti juga memberikan dorongan kepada siswa agar semangat dalam belajar sehingga nanti dalam proses permainan mereka dapat menjawab pertanyaan yang diajukan serta memberi penjelasan kepada mereka agar tidak takut ketika mendapat giliran memegang tongkat sehingga harus menjawab, karena juga disampaikan oleh peneliti bahwa mereka semua pasti akan mendapat giliran memegang tongkat dan menjawab pertanyaan.

B. Penyajian Materi dalam Proses Pembelajaran

Penyajian materi dilakukan setelah tahap awal pelaksanaan pembelajaran diselesaikan. Penyajian materi bertujuan agar siswa mempunyai gambaran yang jelas tentang materi yang akan dipelajari, sehingga para siswa dapat belajar dengan acuan yang telah dijelaskan oleh guru sebelumnya. Penyajian materi dilakukan dengan cara guru hanya memberikan gambaran ataupun garis besar mengenai materi yang dipelajari selebihnya siswa dituntut agar lebih mandiri dalam belajar sehingga ketika dalam proses pembelajaran talking stick nantinya mereka tidak merasa kesulitan dalam menjawab pertanyaan.

C. Proses Pembelajaran Model Pembelajaran Talking Stick

Dalam proses pembelajaran ini para siswa akan mengalami proses pembelajaran yang mereka rasa sangat menyenangkan. Suasana belajar yang biasa mereka rasakan sehari-hari yang sangat membosankan akan berubah menjadi suasana belajar yang sangat berbeda dan menyenangkan. Karena semua siswa akan diajak bermain dan belajar yakni dengan bernyanyi dan menjawab pertanyaan. Akan tetapi, dalam proses pembelajaran ini siswa harus dapat menguasai materi dengan baik agar tidak kesulitan dalam menjawab pertanyaan. Setelah proses pembelajaran ini dilaksanakan dan jika semua siswa sudah menanamkan hal ini difikirannya tidak akan ada lagi siswa yang pasif dikelas, perasaan tertekan, kemungkinan kegagalan dalam ulangan harian, keterbatasan pilihan, dan tentu saja rasa bosan. Semua akan menjadi menyenangkan sehingga proses belajar mengajar menjadi lebih baik.

D. Pemberian Tugas

Dalam proses pembelajaran ini penilaian dilakukan ketika siswa dapat menjawab pertanyaan yang diberikan ketika mereka mendapat giliran memegang tongkat. Guru sudah dapat memberikan penilain ketika proses pembelajaran berlangsung. Disamping itu penilaian juga dilakukan dengan memberikan tugas kepada siswa yang diberikan selama dan sesudah proses pembelajaran berlangsung meski tidak setiap pertemuan tugas yang diberikan selama proses pembelajaran berlangsung. Hal ini dilakukan untuk mengukur dan mengetahui hasil prestasi siswa dalam belajar dan seberapa jauh siswa dapat mengambil atau mengerti isi materi yang telah diberikan.

Pada siklus I ini aktivitas peserta didik dalam penerapan model pembelajaran talking stick sudah cukup baik, meskipun masih ada beberapa kekurangan seperti keaktifan siswa dalam bertanya ketika diberikan kesempatan oleh guru untuk bertanya setelah guru menyampaikan inti materi, dan dalam ketika diberi kesempatan untuk belajar secara mandiri sebelum model pembelajaran talking stick dilaksanakan kebanyakan siswa masih ramai sendiri dan kurang mau untuk belajar padahal sudah diberikan bahan ajar, dan juga ketika proses model pembelajaran talking 
stick dilaksanakan siswa aktif hanya sebatas bernyanyi saja sedangkan ketika menjawab pertanyaan mereka saling melempar satu sama lain. Untuk pekerjaan tugaspun peserta didik masih sangat malas dan banyak yang tidak mengerjakan, sehingga disini kemandirian belajar mereka sangat kurang.Oleh karena itu, untuk meningkatkan aktivitas belajar dan hasil belajar siswa pada mata pelajaran ekonomi, guru melanjutkan siklus I dengan siklus II.

Pada proses pembelajaran model pembelajaran talking stick siklus II ini, aktivitas belajar dan hasil belajar siswa sudah mulai sangat meningkat, hal ini bisa dilihat ketika mereka memperhatikan secara seksama ketika guru menyampaikan materi serta mereka juga dapat mengajukan beberapa pertanyaan mengenai materi yang belum dimengerti, pada saat mereka diberi waktu untuk belajar secara mandiri sebelum metode ini dilakukan merekapun sudah dapat tertib untuk belajar dan tidak ramai sendiri seperti pada siklus I, ketika proses pembelajaran dengan model pembelajaran talking stick dilaksanakan aktivitas merekapun sangat meningkat hal ini dapat dilihat dari mereka tidak takut lagi ketika mendapat giliran manjawab pertanyaan dan mereka sangat semangat dan antusias sekali ketika proses permainan berlangsung.

Hal ini dapat dilihat pada permulaan dari pelaksanaan tindakan pada siklus I perubahan pola pembelajaran yang dulunya hanya selalu bersifat konvensional yakni hanya berpusat pada guru saja, kini siswa mulai diajak untuk berperan aktif dalam proses pembelajaran. Sehingga siswa dapat beraktivitas dan berpartisipasi secara aktif dalam proses pembelajaran. Siswa berdiri untuk menjawab pertanyaan yang diajukan ketika mendapat giliran memegang tongkat, serta bagaimana mereka dapat secara mandiri untuk belajar dan tidak selalu tergantung pada apa yang diberikan oleh guru saja. Hal ini dimaksudkan untuk membuat suasana kelas menjadi lebih hidup.

Pada dasarnya aktivitas belajar siswa pada siklus I ini tergolong "cukup baik" dengan prosentase rata-rata sebesar $12,9 \%$ dan pada siklus II ini tergolong "baik" dengan prosentase rata-rata sebesar $28,57 \%$ dan hasil belajar siswa pada siklus I ini tergolong "cukup baik" dengan prosentase rata-rata sebesar $5,72 \%$ dan pada siklus II ini tergolong "baik" dengan prosentase rata-rata 9,02\%.

Dalam proses permainan siswa hanya semangat ketika bernyanyi meskipun masih ada beberapa siswa yang masih pasif, dan ketika nyanyian berhenti kebanyakan siswa saling ribut sendiri untuk saling melempar tongkat agar terhindar dari pertanyaan. Untuk itu setelah proses pembelajaran ini berlangsung meskipun kurang maksimal, guru memberikan tugas kepada siswa dengan tujuan agar mereka dapat belajar dirumah dan mengulangi materi yang telah diberikan pada pertemuan tadi, akan tetapi masih banyak sekali siswa yang tidak mengerjakaan. Dalam siklus I ini guru senantiasa memberikan stimulus untuk mendorong semangat siswa supaya mereka aktif dalam permainan dan tidak takut lagi ketika mendapat giliran menjawab serta mereka harus dapat mengerjakan tugas yang diberikan agar mereka tidak lupa dengan materi yang telah diajarkan.

Kenyataan di atas dapat dimaklumi mengingat subyek belum pernah belajar dengan menggunakan model pembelajaran seperti ini sebelumnya. Dan masih sangat terbiasa dengan menggunakan model pembelajaran yang masih sangat terpusat pada apa yang diberikan oleh guru, hal ini mengakibatkan siswa mengalami kesulitan dalam menyesuaikan 
diri dalam mengikuti pembelajaran ini pada siklus I sehingga kegiatan pembelajaran dengan model pembelajaran talking stick berjalan kurang sesuai dengan apa yang diharapkan. Dari hasil pengamatan pada siklus I ternyata ada beberapa faktor yang mempengaruhi aktivitas belajar dan hasil belajar siswa dalam proses pembelajaran ini, antara lain:

1. siswa masih terbiasa belajar dengan model pembelajaran sebelumnya sebelum proses pembelajaran dengan model pembelajaran talking stick dilaksanakan.

2. penerapan pembelajaran dengan model pembelajaran talking stick ini masih baru pertama kali diterapkan.

3. siswa masih merasa takut untuk menjawab pertanyaan ketika mendapat giliran memegang tongkat.

4. siswa masih sangat malas untuk mengerjakan tugas di rumah

5. sebelum siswa diberikan bahan ajar oleh peneliti mereka tidak memiliki pegangan atau panduan untuk beajar hanya tergantung dengan apa yang dicatatkan di papan tulis.

Pada pelaksanaan siklus II ini, aktivitas belajar dan hasil belajar siswa mulai mengalami peningkatan, hal ini terlihat dari peningkatan aktivitas belajar siswa dengan peningkatan prosentase sebesar 28,57\% dengan predikat kategori "baik". Sedangkan hasil belajar siswa dengan peningkatan prosentase sebesar $9,02 \%$ dengan predikat kategori "baik". Sebagian besar siswa sudah mulai berpartisipasi secara aktif, bertanya kepada guru mengenai materi yang belum dimengerti dan juga ketika proses pembelajaran dengan model pembelajaran talking stick dilaksanakan mereka tidak lagi merasa takut manjawab pertanyaan ketika mendapat giliran memegang tongkat, serta merekapun sudah mulai mau mengerjakan tugas yang diberikan oleh guru.

Peningkatan aktivitas belajar dan hasil belajar tersebut dimungkinkan terjadi karena selama pelaksanaan tindakan siklus II telah dilakukan perubahan pada proses pembelajaran yang merupakan realisasi langkah perbaikan tindakan siklus I.

Yaitu adanya motivasi yang diberikan oleh guru bahwa pertanyaan yang akan diberikan sudah tersaji pada bahan ajar yang telah diberikan sehingga siswa hanya perlu mempelajari dengan baik, ketika guru menjelaskan inti dari materi pelajaran, selain siswa bertanya guru juga memberikan beberapa pertanyaan kepada siswa yang pertanyaan itu juga merupakan jenis pertanyaan yang akan diberikan pada waktu proses pembelajaran dengan model pembelajaran talking stick sehingga siswa dapat memperdalam materi tersebut dan tidak kesulitan lagi menjawab pertanyaan ketika model pembelajaran talking stick dilaksanakan.

\section{PENUTUP \\ Simpulan}

Berdasarkan hasil análisis dan pembahasan, penelitian tindakan kelas inidapat disimpulkan:

1. pengaruh penggunaan model pembelajaran talking stick terhadap aktivitas belajar siswa kelas $\mathrm{x}-2$ pada mata pelajaran ekonomi sma negeri bandar kedungmulyo, pada pelaksanaan siklus I aktivitas belajar siswa mendapatkan hasil yang cukup baik dengan prosentase sebesar $12,9 \%$. sedangkan pada siklus II aktivitas belajar siswa meningkat dengan mendapatkan hasil yang baik dengan prosentase $28,57 \%$. sehingga dapat disimpulkan, bahwa model pembelajaran talking stick terhadap aktivitas belajar siswa berpengaruh baik.

2. pengaruh penggunaan model pembelajaran talking stick terhadap hasil belajar siswa kelas $\mathrm{x}-2$ pada mata pelajaran ekonomi sma negeri bandarkedungmulyo, pada pelaksanaan siklus I hasil belajar siswa mendapatkan hasil yang cukup baik 
dengan prosentase sebesar 5,72\%. sedangkan pada siklus II hasil belajar siswa meningkat dengan mendapatkan hasil yang baik dengan prosentase $9,02 \%$. sehingga dapat disimpulkan, bahwa model pembelajaran talking stick terhadap hasil belajar siswa berpengaruh baik.

3. pengaruh penggunaan model pembelajaran talking stick terhadap aktivitas belajar dan hasil siswa kelas $\mathrm{x}-2$ pada mata pelajaran ekonomi sma negeri bandarkedungmulyo, pada pelaksanaan siklus I aktivitas belajar siswa mendapatkan hasil yang cukup baik dengan prosentase sebesar 12,9\%, hasil belajar siswa mendapatkan hasil yang cukup baik dengan prosentase sebesar 5,72\% sedangkan pada siklus II aktivitas belajar siswa meningkat dengan mendapatkan hasil yang baik dengan prosentase $28,57 \%$, hasil belajar siswa mendapatlan hasil yang baik dengan prosentase $9,02 \%$. sehingga dapat disimpulkan, bahwa model pembelajaran talking stick terhadap aktivitas belajar dan hasil belajar siswa berpengaruh baik.

\section{DAFTAR PUSTAKA}

Anni, Catharina Tri. 2004. Psilologi belajar. Semarang: UPT MKK UNNES.

Depdiknas. 2003. Kurikulum 2004 Standar Kompetensi Mata Pelajaran Ekonomi dan Akuntansi Sekolah Menengah Atas. Jakarta: Depdiknas.

Dimyati dan Mudjiono. 2006. Belajar dan Pembelajaran. Jakarta: Rineka Cipta.

Dwi Prasetyani, Ulfi. 2010. Peningkatan Hasil Belajar dengan Menggunakan Metode Pembelajaran SQ4R (Survey, Question, Read, Reflect, Recite, Review) melalui Pendekatan Talking Stick pada Mata Pelajaran Biologi Kelas VIII Pokok Bahasan System
Peredaran Darah di SMP Negeri 31 Semarang.Semarang : Fakultas dan Ilmu Pendidikan Kurikulum dan Teknologi Pendidikan UNS

Fani, Anato (2010) dalam penelitiannuya yang berjudul "Pengaruh Penerapan Metode Talking Stick Terhadap Hasil Belajar Pendidikan Agama Islam di Smp Negeri 4 Surabaya."

FX.Sudarsono. 2001.Apikasi Penelitian Tindakan Kelas. Jakarta. Pusat Antar Universitas Untuk Peningkatan dan Pengembangan Aktivitas Instruksional Dirjen Dikti Depdiknas.

E.Mulyasa. 2007.Standar Kompetensi dan Sertifikasi Guru. Bandung: PT Remaja Rosdakarya.

Munawar, Indra. 2009. Hasil Belajar (Pengertian dan Definisi). http://indramunawar.blogspot.com/200 9/06/hasil-belajar-pengertian-dandefinisi.html (diakses tanggal 24 Oktober 2011)

Nasih, Ahmad Munjin dan Lilik Nur Kholidah, 2009. Metode dan Tehnik Pembelajaran Pendidikan Agama Islam. Malang: PT Refika Aditama.

Nawawi, Hadari. 2005. Metode Penelitian Bidang Sosial. Gajah Mada University Press

Nur'aini, Alvi (2006) dalam penelitiannya yang berjudul "Pengaruh Model Pembelajaran Talking Stick dan Numbered Head Together untuk Meningkatkan Aktivitas dan Hasil Belajar Siswa pada Mata Pelajaran Ekonomi."

Nur, M dan Wikandari, P.R. 2000.Pengajaran Berpusat Kepada Siswa dan Pendekatan Kontruktivis dalam Pengajaran. Surabaya: PSMS program pascasarjana Unesa. 
Sidi, Indra Jati. 2004. Kurikulum SMK Edisi 2004. Jakarta: Departemen Pendidikan Nasional

Wahab Abdul Aziz. 2008.Metode dan ModelModel Mengajar, Bandung:Alfabeta.
Wahidmurni dan Nur Ali, 2008. Penelitian Tindakan Kelas. Surabaya: UIN press.

Winkel, W.S. 2005.Psikologi Pengajaran. Jakarta : PT. Gramedia Pustaka Utama 